\title{
A Taxonomic Review of the Korean Atractomorpha Saussure, 1862 (Orthoptera: Caelifera: Pyrgomorphidae)
}

Tae-Woo Kim*

Invertebrate Research Division, National Institute of Biological Resources, Gyeongseo-dong, Seo-gu, Incheon, 404-170, Korea

\section{한국산 섬서구메뚜기속(Atractomorpha)의 분류학적 검토}

김태우*

국립생물자원관 무척추동물연구과

\begin{abstract}
A taxonomic review of the genus Atractomorpha Saussure in Korea is presented. Two species are identified, Atractomorpha lata (Motschulsky, 1866) and a new record A. sinensis Bolívar, 1905 which is reported from the far southern islands in Korea, Gageo-do and Jeju-do. A key, descriptions, habitus photographs of adults, and distributional information are provided.
\end{abstract}

KEY WORDS : Taxonomy, Orthoptera, Pyrgomorphidae, Atractomorpha, Korea.

초 록 : 한국산 섬서구메뚜기속(Atractomorpha)의 분류학적 검토를 통해 섬서구메뚜기(Atractomorpha lata (Motschulsky, 1866))와 분홍날개섬서구메뚜기(신칭)(A. sinensis Bolívar, 1905) 두 종을 확인하였다. 이 중 분홍날개섬서구메뚜기는 한반도 남단의 섬 제주도와 가거도로부터 처음 보고되는 한국 미기록종이 다. 두 종을 비교하여 동정할 수 있는 검색표, 기재, 사진 및 분포 정보를 제시하였다.

검색어 : 분류, 메뚜기목, 메뚜기아목, 섬서구메뚜기과, 섬서구메뚜기속(Atractomorpha)

The representative genus Atractomorpha Saussure of the family Pyrgomorphidae, contains 27 species mostly distributed in the Old World tropics and subtropics (Eades and Otte, Orthoptera Species File Online). In Korea, a single and common species Atractomorpha lata (Motschulsky, 1866) has been known in almost provinces since Walker's record (1870) although that with a few different synonymies (= Perena concolor, $=$ Atractomorpha bedeli, $=$ Atractomorpha heteroptera . It was very few, comparing with those in neighboring countries such as Japan with three (OSJ, 2006) and China with 20 species (Hua, 2000).

The genus Atractomorpha is easily recognized by a conical head (Figs. 3 and 4), the vertex finely drawn groove or fastigial furrow at its tip. These grasshoppers being polyphagous, which can eat on various vegetables and crops, accordingly listed as a one of major agricultural pests in the world (COPR, 1982). The Atractomorpha lata is also recorded as one of pest species in Korea (Korean Society of Plant Pathology, 1986; Forestry

*Corresponding author. E-mail: pulmuchi@korea.kr 
Research Institute, 1995).

In this report, the author examined more than 2,000 specimens from Korean peninsular and attached archipelago. Among them a newly identified Atractomorpha species is found from far southern islands, Gageo-do and Jeju-do. That is Atractomorpha sinensis Bolívar, 1905.

In addition to as a pest status with economic importance, to understand biogeographical events in the congeneric species around the Korean peninsular, it would be advisable to have an exact information for the taxa. Here I suggest a taxonomic key, descriptions for detailed comparison, distributional data, photographs for comparative identification regarding with the genus Atractomorpha in Korea.

\section{Materials and Methods}

The materials examined are deposited in following abbreviations: $<\mathrm{GSU}>$ Gyeongsang University, Jinju, KOREA; $<$ HNHM $>$ Hungarian Natural History Museum, Budapest, HUNGARY; <KU $>$ Korean University, Seoul, KOREA; $<$ NHM $>$ The Natural History Museum, London, UK; $<$ NIBR $>$ National Institute of Biological Resources, Incheon, KOREA; $<$ SNU $>$ Seoul University, Seoul, KOREA; $<$ SSU $>$ Sungshin Women's University, Seoul, KOREA.

The Korean geographic names have been taken from the Ministry of Culture and Tourism (2000), the abbreviations for the provinces are followings as: $\langle\mathrm{PN}\rangle$ Pyeongannam-do; $<\mathrm{GW}>$ Gangwon-do; $<\mathrm{GS}>$ Gyeonggido and Seoul; $<\mathrm{CB}>$ Chungcheongbuk-do; $<\mathrm{CN}>$ Chungcheongnam-do; $<\mathrm{GB}>$ Gyeongsangbuk-do; $<\mathrm{GN}>$ Gyeongsangnam-do; $<\mathrm{JB}>$ Jeollabuk-do; $<\mathrm{JN}>$ Jeollanamdo; $<$ JJ $>$ Jeju-do.

The photographs of the body are taken from using the Canon EOS 5 Camera, EOS 20D Digital Camera, the head and pronotum are taken from Olympus Digital Camera system attached at an Olympus microscope. The voucher specimens of newly recorded species Atractomorpha sinensis are kept in NIBR.

\section{Systematics}

\section{Genus Atractomorpha Saussure, 1862}

Annales de la Société Entomologique de France, 4(1): 474 (Type species: Truxalis crenulatus Fabricius, 1793).

$=$ Perena Walker, 1870. Catalogue of the Specimens of Dermaptera Saltatoria in the Collection of the British Museum, 3: 506 (Type species: Perena concolor Walker, 1870). [Kirby, 1910]

Diagnosis. Body elongated fusiform. Head conical, frontal profile very strongly oblique. Fastigium of vertex well developed, lanceolate to pyramidal in outline as seen from above. Tegmina well developed, usually extending beyond the apex of the abdomen, acute lanceolate at apex, narrower in male than in female. Prosternal tubercle obliquely truncated. Mesosternal interspace trapezoidal, narrower particularly in the male. Metasternal interspace ellipsoidal or oblong. Epiproct elongate trigonal. Cerci short and conical. Epiphallus with middle portion anchor-shaped. Ovipositor with dorsal valves sinuate and crenulated (Bey-Bienko and Mishchenko, 1951; Banerjee and Kevan, 1960).

\section{Key to Species of the Atractomorpha in Korea}

1. Fastigium of vertex longer than the longitudinal diameter of an eye in dorsal view; postocular granules 10-12 (Fig. 3); pronotum with distinct lateral carinae; prozona clearly longer than metazona; paranotum without membranous area near posterior margin; hind wings transparent, without remarkable coloration $\cdots \cdot \cdot$... A lata

- Fastigium of vertex as long as the longitudinal diameter of an eye in dorsal view; postocular granules 8-10 (Fig. 4); pronotum with indistinct lateral carinae; prozona as long as metazona; paranotum with membranous area near posterior margin; hind wings rosy or bright pink in basal half sinensis 
Atractomorpha lata (Motschulsky, 1866) 섬서구메뚜기 (Table 1, Figs. 1 and 3)

Truxalis lata Motschulsky, 1866. Bull. Moscou. obshchestva ispyt. prirody, 39(1): 181. "Japan" (Type lost): Atractomorpha lata: Bey-Bienko and Mishchenko, 1951: 277, Fig. 570; Kevan, 1963: 85, pl. 12; Steinmann, 1967: 565, Fig. 1F; Rentz and Miller, 1971: 256; Inoue, 1985: 137, Figs. 31, 62, 93; Tadauchi, 1989: 54; Kwon and Huh, 1994: 51; Xia et al., 1994: 293, Figs. 162, 163c, d; Huh and Kwon, 1995: 9; Moon and Yoon, 1996: 52; Kwon et al., 1996: 104; Yin et al., 1996: 79; Chung et al., 1997: 535; Hua, 2000: 35.

= Perena concolor Walker, 1870 (partim). Catalogue of the Specimens of Dermaptera Saltatoria in the Collection of the British Museum, 3: 506. "Corea" (Lectotype + in NHM London). [Banerjee and Kevan, 1960]

= Atractomorpha bedeli Bolívar, 1884. Anales de la Sociedad Española de Historia Natural, 13: 64. "Japan: Yokohama" (Lectotype + in Instituto Espanol de Entomologia, Madrid). [Banerjee and Kevan, 1960]: Ikonnikov, 1913: 19; Doi, 1932: 34; Haku, 1937: 73; Furukawa and Shiraki, 1950: 26, Fig. 58; Kang and Son, 1958: 21; Cho, 1959: 171, Fig. 50; Cho and Lee, 1959; 8; Cho, 1969: 728, pl. 48; Ju, 1969: 22; Acrida [!] bedeli: Kim et al., 1987: 216.

= Atractomorpha heteroptera Bey-Bienko, in Bey-Bienko and Mishchenko, 1951. Locusts and Grasshoppers of the U.S.S.R. and Adjacent Countries, 1: 275, Figs. 565, 566, 569. "China: Manchuria" (Holotype + in Zoological

Table 1. Measurements (lengths) of Atractomorpha spp. (from dry specimens)

\begin{tabular}{|c|c|c|c|c|c|}
\hline Species & Body & Head to tegminal end & Pronotum & Tegmen & Hind femur \\
\hline \multirow{2}{*}{ A. lata } & $\sigma^{7} 19.7-22.0$ & $\sigma^{7} \quad 22.7-27.8$ & $\sigma^{7} 4.2-4.5$ & $\sigma^{7} 15.0-18.6$ & $\sigma^{7} 9.3-12.0$ \\
\hline & 우 30.8-38.8 & 우 37.8-46.4 & 우 7.8-8.4 & 우 27.0-32.0 & 우 $15.5-17.8$ \\
\hline \multirow{2}{*}{ A. sinensis } & $\sigma^{7} \quad 19.4-22.5$ & o $23.1-29.4$ & $0^{7} 3.7-4.4$ & $\sigma^{7} \quad 16.7-21.4$ & $\sigma^{7} 8.7-10.8$ \\
\hline & 우 $26.4-30.8$ & 우 $32.4-38.8$ & 우 $6.0-6.6$ & 우 23.0-28.4 & 우 12.3-13.4 \\
\hline
\end{tabular}

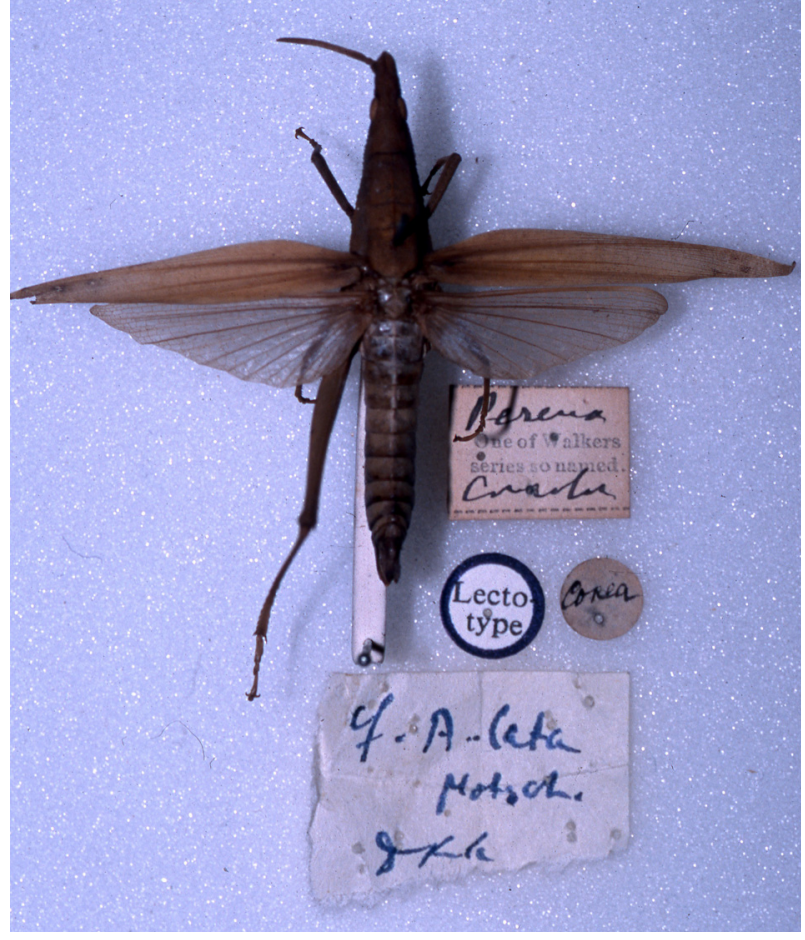

Fig. 1. Lectotype female of Perena concolor (= Atractomorpha lata) collected from 'Corea' with most early history (deposited in the NHM, London).

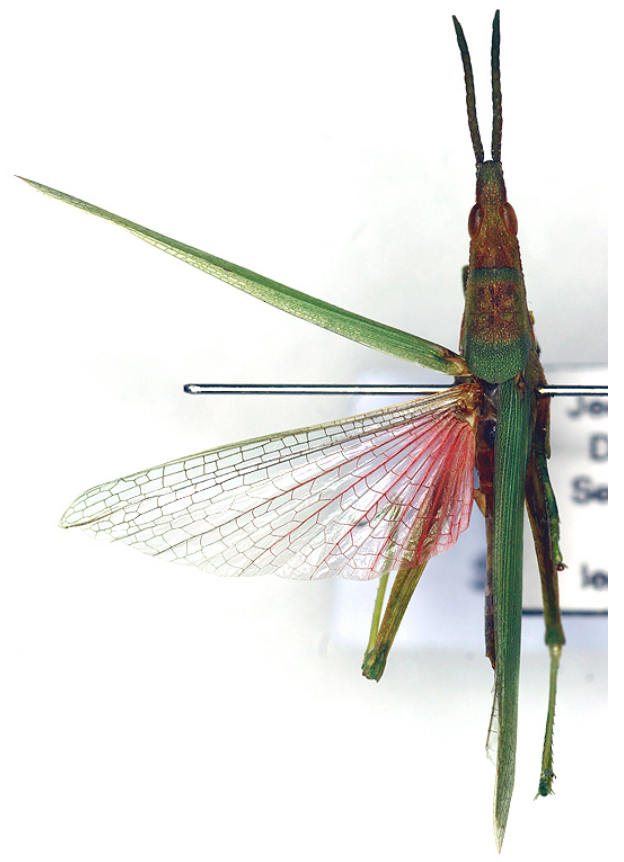

Fig. 2. Body habitus of Atractomorpha sinensis, a male with pinkish hind wings which collected from Is. Jeju-do. 
Institute of the Russian Academy of Sciences, St. Petersburg). [Kevan, 1963]: Atractomorpha brevicornis heteroptera: Banerjee and Kevan, 1960: 186; Tsyplenkov, 1970: 214.

Truxalis brevicornis Thunberg, 1815. Mémoires de l'Académie Impériale des Sciences de St. Pétersbourg, 5: 264. "China" (Holotype $\sigma^{\top}$ in Zooligical Institute, Uppsala University, Uppsala). Nom. nub. since Kevan (1963): Atractomorpha brevicornis brevicornis: Banerjee and Kevan, 1960: 186, Figs. 10, 16, 26, 37, 43.

Specimens examined. <Lectotype $>1$ 우 "Corea", date unknown, E. Belcher (NHM); $<\mathbf{P N}>40^{x} 2$ \%, Sagam $45 \mathrm{~km} \mathrm{~N}$ from Pyongyang, 12 viii 1971, S. Horvatovich and J. Papp, No. 163 (HNHM); 1 , Chang-lyong san $50 \mathrm{~km} \mathrm{~N}$ of Pyongyan and $15 \mathrm{~km}$ E from Sa-gam, 13 viii 1971, S. Horvatovich and J. Papp, No. 168 (HNHM); $10^{7} 1$, Bongwa-ri on the riverside Te-dong about $45 \mathrm{~km}$ E from Pyongyan, 16 viii 1971, S. Horvatovich and J. Papp, No. 178 (HNHM); $20^{7} 2$ \% , Zamo san $60 \mathrm{~km}$ NE from Pyongyan, 2 ix 1971, S. Horvatovich and J. Papp, No. 230 (HNHM); <GW $>2$ ㅇ, Geondongsa Ganseong, 22 viii 1993, Moon TY (KU); 1 , , Naegokdong Gangneung, 12 ix 1993, Jang MA (SSU); 1 , Buyeongyegok Samsan-ri Yeongok Gangneung, 18-19 viii 2001, Kim JI (SSU); 1 , Cheongok-dong Donghae, 23 viii 1998, Lee HH (SSU); 1 ㅇ, Mt. Seolaksan Sokcho, 20 vii 1998, Nam MA (SSU); 1 \& , Mt. Chiaksan Wonju, 19 vii 1998, Kim SA (SSU); 19 , Seohwa Inje, 29 viii 1990, Park HC (SSU); 1 ㅇ, Soyanggang Chuncheon, $1 \times 1983$, No YM (SSU); 1 오, Cheongpyeongsa Chuncheon, 31 vii 1994, Shin JH (SSU); 1 \% , Mt. Odaesan Jinbu Pyeongchang, 16 viii 1990, Lee MS (SSU); 1 \&, Noil-ri Hongcheon, 19 ix 1993, Kim SJ (SSU); <GS> $30^{\top} 2$ 오, Mt. Myeongjisan Gapyeong, 23 ix 1989, Park JM et al. (SSU); $10^{\top}$, Gyodongdo Ganghwa-do Incheon, 17 viii 1987, Yoo HJ (SSU); 1 ㅇ, Seokmodo Ganghwado Incheon, 27 ix 1992, Moon TY (KU); 1 , Mt. Surian Gunpo, 7×2001, Kim TW (SSU); 10", Maseok Namyangju, 17 ix 1988, Sim HJ (SSU); 2 9 , Namhansanseong Seongnam, 17 ix 1988, Kim JH (SSU); 107, Yeongcheongdong Masan-ri Miyang-myeon Anseong, 28 viii 2003,
Yeo JD (KU); $10^{\star}$, Munbal-ri Paju, 9 ix 1998, Jang HY (SSU); 1 , Rodriguez shooting range Yeongpyeong Pocheon, 21 ix 1996, Kim JI and Park HC (SSU); 107, Hyangnam Hwaseong, $1 \times 1988$, Lee MO (SSU); $20^{\top} 2$ 우 , Mt. Cheonggyesan Gangnam-gu Seoul, $8 \times 1988$, Oh HJ (SSU); 1 , Hagye-dong Nowon-gu Seoul, 20 vii 1998, Lee HJ (SSU); 2 , Mt. Dobongsan Seoul, 24 viii 1988, Kang JH (SSU); 1 , Jamsil Seoul, 2 ix 1977, Kim BS (SSU); 1 으, Mt. Manisan Ganghwa-do Incheon, 12 viii 1996, Shin HJ (SSU); <CB $>2$ q, Hwayang-ri Cheongcheon Goesan, 15 ix 1984, Kim YS (SSU); 20*, Yongam-ri Hwanggan-myeon Yeongdong, 4-5 viii 2001, Kim AY (SSU); 2 ㅇ, Sojeong-ri Gunbuk Okcheon, 23×1990, Kim JI and Park HC (SSU); 10", Mt. Wolaksan Jecheon, 29 viii 1994, Kim JH (SSU); 1 ㅇ, Danwol-dong Chungju, 14 ix 1996, Jeon YH (SSU); 30", Mt. Cheondeungsan Sancheok-myeon Chungju, 28 viii 2002, Kim TW (SSU); $<\mathbf{C N}>1$ \% , Mok-dong Jung-gu Daejeon, 8 viii 1997, Lee NY (SSU); $10^{\text {" }}$, Hoedeok Daejeon, 26 viii 1997, Kim BY (SSU); 1 , Mt. Gyeryongsan Gongju, 15 viii 1993, Lee GA (SSU); $10^{\star}$, Gongsanseong Okryong Gongju, 15 viii 1988, Moon G (SSU); $10^{7}$, Dusan-ri Dangjin, 18 viii 1984, Choi HS (SSU); 1 , Wungcheon Boreong, 15 viii 1989, Jang EJ (SSU); 3 \%, Hyudae-ri Asan, 20 ix 1992, Kim HJ (SSU); 10", Cheonan, $7 \times 1996$, Jeong JY (SSU); <GB $>20^{*}$, Mt. Palgongsan Daegu, 8×1991, L. Zombori (HNHM); $10^{x}$, Hyoseong Univ. Geongsan, 7 vii 1992, Yoon HG (SSU); 1 , Ubo-myeon Gunui, 18 ix 1994, Park YH (SSU); 1 \%, Gwaneum-ri Mungyeong, 18 ix 1986, Jeong MS (SSU); 107, Deokgol-ri Gongseong Sangju, 13 viii 1985, Kim OH (SSU); 10", Waryong Andong, 22 ix 1991, An HJ (SSU); 1 ㅇ, Jangsu Yeongju, 5×1998, Lyu JY (SSU); 1 으, Mt. Juwangsan Cheongsong, 16 viii 1990, Lee JA (SSU); $<$ GN $>1$ 우, Geompo, 17 ix 1997, No JY (SSU); 1 올 Deokgye, 18 viii 1996, Park HG (SSU); 1 , Yaeum Ulsan, 22 ix 1991, Sim SJ (SSU); 10", Yeonyang-myeong Ulju, 29 vii 1989, Park HM (SSU); 1 , Nabul-ri Jinyang, 15 viii 1992, Kim GY (GSU); 107, Banrim-dong Changwon, 24 viii 1994, Kim AR (SSU); 1 \%, Donam-dong Chungmu, 11 ix 1992, Shin MJ (SSU); 1 올 Hapcheon, 12 ix 1992, Park HH (SSU); 2오, Naewonjeongsa 
Busan, 25 viii 1996, Park EG (SSU); 1 ㅇ, Yeonsandong Dongnae Busan, 21 viii 1985, Park MN (SSU); $<\mathbf{J B}>10^{\top} 1$ ㅇ, Buan Gochang, 11 ix- $25 \times 1992$, Choi HJ (SSU); 1 ㅇ, Toji-myeon Gurye, 27 ix 1996, Hun R (SSU); 1 오, Unbong Namwon, 30 ix 1984, Chang KS (SSU); 1 , Mt. Naejangsan, $18 \times 1980$, Wu GS (SNU); 1 , Mt. Deokyusan Muju, 9 viii 1984, Shon JH (SSU); 1 으, Bongeun-ri Buan, 10×1981, Chang KS (SSU); 1 ㅇ, Yongdeok Wanju, 26 vii 1996, Lee $\mathrm{CH}$ (SSU); 10", Pyeonghwa-dong Iri, 10 viii 1987, Kim HJ (SSU); $<\mathbf{N}>10^{7}$, Okryong-myeon Gwangyang, 14 viii 1994, Shin JH (SSU); 1 \%, Mt. Mudeungsan Seo-gu Gwangju, 10×1988, Im WS (SSU); 1 , Naju, 2 viii 1996, Im IH (SSU); 1 , Taein Donggwangyang, 20 ix 1994, Jeong HJ (SSU); 1 ㅇ, Mt. Yudalsan Mokpo, 10 viii 1988, Kwon MK (SSU); 1 , Is. Sangbaekdo Samsan-myeon Yeosu, 13×2001, Yoon IB (SSU); 1 오, Soho-dong Yeosu, 23 ix 1991, Sim SJ (SSU); 1 오 , Jukpo-ri Yeocheon, 6×1998, An EG (SSU); 1 ㅇ, Is. Bogildo Wando, 23 viii 1982, Chang KS (SSU); 1 으, Jagaedo Wando, 23 viii 1982, Kim JI (SSU); 1 옥 Is. Hoenggando Wando, 22 viii 1982, Chang KS (SSU); 1 , , Baekyangsa Jangseong, 12 viii 1989, Kang YH (SSU); 1 , , Hwangryong Jangseong, 9 viii 1996, Kim MJ (SSU); <JJ $>20^{\top} 15$ 오 , Doloreum, $3 \times 2003$, Park SH et al. (NIBR); 1 오 , Saetbyeoloreum, $3 \times 2003$, Park SH (NIBR); $3+$, Soroksan Jeju-si, Park $\mathrm{SH}$ et al. (NIBR); $10^{\top} 6$ \% , Uitbamoreum, $3 \times 2003$, Park $\mathrm{SH}$ et al. (NIBR); $10^{\top} 2 \%$, Seonheul-ri Jocheon-eup Jeju-si, 29 ix 2006, Jung SH (NIBR); $1 \%$, Ora-dong Jeju-si, 6 vi 2006, Jung SH (NIBR); 1 , Nohyeongdong Jeju-si, 6 vii 2006, Jung SH (NIBR).

Description. $\left\langle\sigma^{x}\right\rangle$ Body slender and elongated, coloration generally pale green, sometimes brown, gray, or pinkish variable. Head conical with incurved frons. Antennae thick filiform, but basal part rather triangular in cross section. Fastigium of vertex longer than the horizontal diameter of an eye in lateral view. Interocular distance in dorsum 1.5 times wider than the horizontal diameter of an eye. Median ocellus located between slightly lower margin of eyes. Pronotum with fairly strong and well defined middle and lateral carinae. Pronotum with prozona clearly longer than metazona; pronotal disk long than the height of lateral lobe. Paranotum without transparent area near posterior margin. Along behind eyes and lateral lower margins of paranotum with numerous white small granule lines. Prosternum with a rectangular tongue-shaped tubercle. Tegmina slender and macropterous, its apex sharply pointed. Wings transparent, weakly tinged with yellow in basal half. Tympana large ovoidal, clearly opened, without covering lobe. Mesosternal interspace rectangular, longer than wide. Epiproct elongated triangular, clearly longer than subgenital plate. Cercus conical, rather incurved at apex, 2.5 times longer than the basal width. Subgenital plate very short and round pouchform. $<q>$ Larger than male. Interocular distance in dorsum two times wider than horizontal diameter of an eye. Mesosternal interspace trapezoidal, the width of median as wide as long. Epiproct long triangular. Cercus very short and conical, as long as basal width. Ovipositor with very thick dorsal valves than ventral valves; ventral valves as long as subgenital plate.

Distribution. Korea, Japan, Northeast China.

Remarks. This species is considered to distribute only around Far Eastern Asia of which origin centered in the Korean peninsular. According to the map presented by Banerjee and Kevan (1960), the Atractomorpha lata is a substitute closest species of A. sinensis along with geographical gradient from southwest to northeast.

\section{Atractomorpha sinensis sinensis Bolivar, 1905} 분홍날개섬서구메뚜기(신칭)(Table 1, Figs. 2 and 4)

Atractomorpha sinensis Bolívar, 1905. Boletín de la Real Sociedad Española de Historia Natural, 5: 205. "China" (Holotype + in Museum National d'Histoire Naturelle, Paris).

Specimens examined. $<\mathbf{J N}>20^{\circ}$, Is. Gageodo Heuksanmyeon Sinan-gun, 17 xii 2006, Kang EY (NIBR); <JI $10^{7}$, Jeongbangpokpo Dongheung-dong Seoguipo-si, 9 vii 2002, Kim TW (NIBR); $10^{2}$, ibid, 16 ix 2009, Kim TW (NIBR); $110^{7} 8 \%$, Namwon-ri Namwon-eup Seoguipo-si, $8 \times 2009$, Park SK (NIBR); Other country $<$ Taiwan $>20^{7} 3$, , Shueishe Sun Moon Lake, 10 vii 


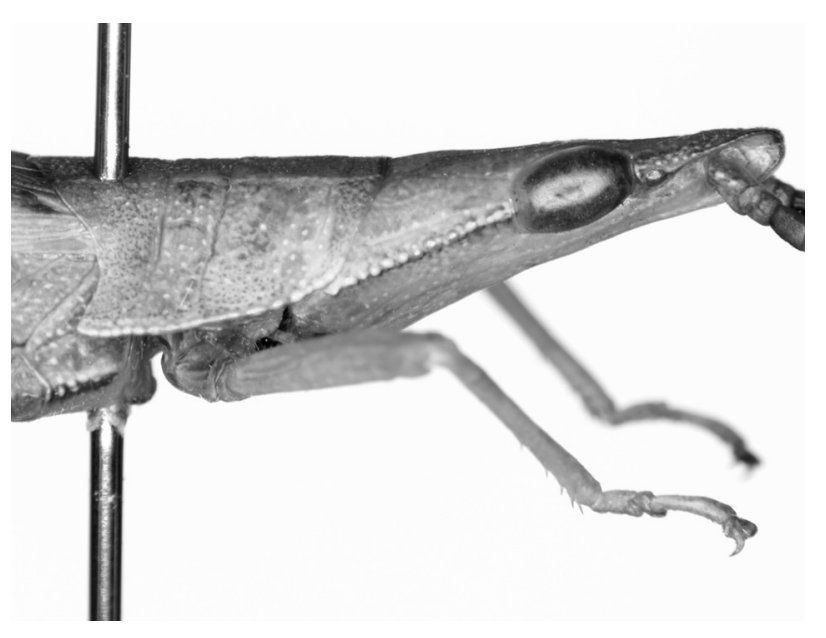

Fig. 3. Atractomorpha lata, head and pronotum of a male.

2001, Kim TW (NIBR); 1 , Mt. Yangmingshan, 14 vii 2001, Kim TW (NIBR).

Description. $<\sigma^{x}>$ Body slender and elongated, coloration green or brown, two contrastive types present. Head conical and tapering forwards. Fastigium of vertex as long as an eye's horizontal diameter. Antennae thick and short, flagellum 13-segmented. Frons strongly slanted, median ocellus present between the lower margins of eyes. Pronotum with many granule and puncture; anterior margin slightly concave, posterior margin protruding with obtuse angle, its median with a small notch; 1st sulcus indistinct, but 2nd and 3rd sulci distinct; prozona as long as or slightly longer than metazona; median carina distinct on whole pronotal disk, but lateral carinae distinct in prozona, indistinct in metazona. Paranotum with a distinct transparent area near the posterior margin; posterior margin widely concave. Small white granules present along behind eye to lower margin of paranutum. Prosternum with a small tubercle tongueshaped, its anterior side rather concave, lower margin rather round, lateral sides perpendicular. Tegmina slender and macropterous, its apex sharply pointed surpassing abdominal end or hind knee; anterior margin with slight convex precostal bulge, but nearly parallel with posterior margin. Wings pinkish in basal half, not surpassing tegminal apex. Mesosternal interspace square, width as wide as long. Tympana large ovoidal without covering lobe. Hind femur slightly longer than abdominal end. Last abdominal tergite with round median concavity, a

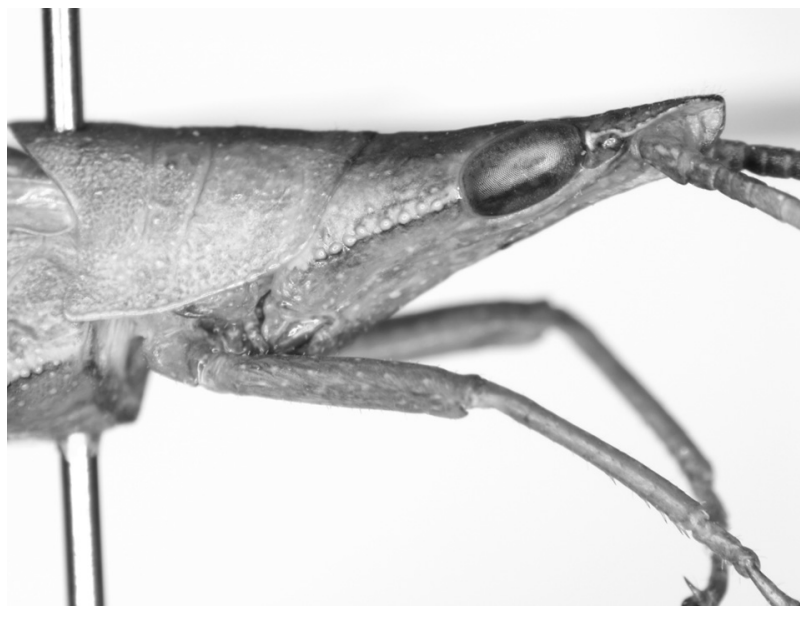

Fig. 4. Atractomorpha sinensis, head and pronotum of a male.

pair of lobe roundly protruding. Epiproct long triangular without any tubercle. Cercus conical, 2.5 times longer than the basal width, shorter than epiproct. Subgenital plate compressed pouch-shaped, slightly longer than epiproct. $<$ $>$ Clearly larger than male. Interocular distance in dorsum two times wider than horizontal diameter of an eye. Mesosternal interspace trapezoidal, the width of median wider than long. Epiproct triangular. Cercus short and conical, 1.2 times longer than basal width. Ovipositor with very thick dorsal valves than ventral valves; ventral valves shorter than subgenital plate.

Distribution. Korea (new record), Japan, China, Taiwan, Hawaii (introduced) (ssp. montana: West Himalaya).

Remarks. This species is characterized by remarkable rosy hind wings and short fastigium when compared with Atractomorpha lata. Quite common grasshoppers in Chinese mainlands, and distribute in Taiwan as well as in Ryu-Kyu Islands of Japan (Kevan and Lee, 1974). Based on this discovery from Korea, it is considered that an evidence about early geographical history, so far southern parts of Korea must be connected with southern China.

\section{Acknowledgments}

The author deeply thank to Mrs. Judith A. Marshall (The Natural History Museum) and Dr. György Sziráki (Hungarian Natural History Museum) for allowing the 
accession to Korean specimens. Also special thank given to Mr. Kang Eu-Yeong, who provided valuable specimens of Atractomorpha collected from Is. Gageo-do where farthest southwestern islands from Korean peninsular. According to him, the grasshoppers were observed to be impale at sharp branches by the true shrikes (Lanius sp.) in December as the bird's wintering diet. Also Mr. Park Sang-Kyu provided a lot of specimens of Atractomorpha sinensis collected from Is. Jeju-do in this year and gave me an additional information for the distribution.

\section{Literature Cited}

Banerjee, S.K. and D.K.McE. Kevan. 1960. A preliminary revision of the genus Atractomorpha Saussure, 1862 (Orthoptera: Acridoidea: Pyrgomorphidae) Treubia, 25: 165-189, 44figs.

Bey-Bienko, G. and L.L. Mishchenko. 1951. Locusts and Grasshoppers of the USSR and adjacent countries. Part 1, 2. 667pp. [English translated, (1964) Israel program]

Cho, P.S. 1959. A manual of the Orthoptera of Korea. Hum. and Nat. Sci. Korea Univ. 4: 131-198.

Cho, P.S. 1969. Orthoptera. In: Illustrated encyclopedia of fauna and flora of Korea, 10(II). Samhwa Publ. Co. pp. 713-800.

Cho, P.S. and B.J. Lee. 1959. The comparative observation on sulca on thoraxes of larvae and adults of Acrididae from KwangNeung, Korea. Bull. Dept. Korea Univ. 2(1-4): 4-16.

Chung, M.G., S.S. Kang and Y. Yeeh. 1997. Genetic structure in Korean populations of Atractomorpha lata (Orthoptera: Pyrgomorphidae). Korean J. Biol. Sci. 1: 535-538.

COPR (Centre for Overseas Pest Research). 1982. The Locust and Grasshopper Agricultural Manual, 690pp.

Doi, H. 1932. Miscellaneous note on Insects. J. Chosen Nat. Hist. Soc. 13: 30-49.

Eades, D.C. and D. Otte. Orthoptera Species File Online. Version 2.0/3.5. [retrieval date]. <http://Orthoptera.SpeciesFile.org $>$.

Forestry Research Institute. 1995. A list of insect pests of trees and shrubs in Korea, 10p.

Furukawa, H. and T. Shiraki. 1950. Iconographia Insectorum Japonicorum. Tokyo, pp. 22-52.

Haku, K. 1937. A list of insects collected from North Keisho-Do, Korea. (No. II). J. Chosen Nat. Hist. Soc. 22: 70-74.

Hua, L. 2000. List of Chinese insects. Vol. 1. Zhongshan (Sun Yat-sen) University Press; Guangzhou.

Huh, E.Y. and Y.J. Kwon. 1995. A check list of the Caelifera from Chejudo (Orthoptera). Ins. Koreana Suppl. 5: 7-18.

Ikonnikov, N. 1913. Über die von P. Schmidt aus Korea mitgebrachten Acridiodeen. Kuznetzk, pp. 1-22. fig 1-2.
Inoue, M. 1985. A taxonomic revision of Japanese Acridoidea (Orthoptera) with special reference to their karyomorphology. Trans. Shikoku Ent. Soc. 17(3): 103-183.

Ju, D.R. 1969. Check list of insect classification. Gwahakwon Publ. Pyeongyang, pp. 16-19.

Kang, Y.S. and H.C. Son. 1958. Studies on the Chromosomes of Orthoptera in Korea (1). Korean J. Zool. 1(1): 17-24.

Kevan, D.K.McE. 1963. Pyrgomorphidae (Orthoptera: Acridoidea) in the collection of C.P. Thunberg, Uppsala, with notes on type material of the species represented. Ark. Zool. Uppsala, 16: 69-96, 15pls.

Kevan, D.K.McE. and S.K. Lee. 1974. Atractomorpha sinensis sinensis Bolivar (Orthoptera: Pyrgomorphidae) and its nymphal stages. Oriental Insects, 8(3): 337-364.

Kim, D.H., J.W. Lee and W.H. Park. 1987. A cytotaxonomic study of six species of the Korean Orthoptera. Korean J. Entomol. 17(4): 215-223.

Korean Society of Plant Pathology. 1986. Names of plants, pest insects, and weeds in Korea. 142p.

Kwon, Y.J. and E.Y. Huh. 1994. Order 14. Orthoptera. In Check list of insects from Korea. Kon-Kuk Univ. Press, pp. 48-53.

Kwon, Y.J., J.H. Lee, S.J. Suh, S.L. An, E.Y. Huh and Y.S. Yeo. 1996. Korean species list. Kor. Nat. Coun. Conser. Nat. pp. 103-104.

Ministry of Culture and Tourism (Eds.), 2000. Romanization reference for Korean place names and cultural terms. The National Institute of the Korean language, Seoul, pp. 1-417.

Moon, T.Y. and I.B. Yoon. 1996. The list of Orthoptera deposited in the Korean Entomological Institute, III. Caelifera, Entomol. Res. Bull. (KEI), 22: 51-54.

OSJ (Orthopterological Society of Japan). [eds.] 2006. Orthoptera of the Japanese Archipelago in color. Hokkaido Univ. 687pp.

Rentz, D.C. and G.R. Miller. 1971. Ecological and faunistic notes on a collection of Orthoptera from South Korea. Ent. News, 82: $253-273$.

Steinmann, H. 1967. New Palaerctic Atractomorpha Sauss. and Pyrgomorpha Serv. species (Orthoptera, Acrididae). Acta ent. Mus. natn. Pragae 37: 565-575.

Tadauchi, O. 1989. Orthoptera. In: A check list of Japanese insects I, pp. 47-57.

Tsyplenkov, Ye.P. 1970. Grasshoppers (Orthoptera: Acridoidea) of the Korean People's Republic. Ent. Obozr. 49: 355-359. [English translated, (1970) Ent. Rev. 49(2): 213-215.]

Xia, K. [eds.] 1994. Acridoidae: Pamphagidae, Chrotogonidae, Pyrgomorphidae. Fauna Sinica Insecta Vol. 4. Science press, Beijing, 340pp.

Yin, X., J. Shi and Z. Yin. 1996. A synonymic catalogue of grasshoppers and their allies of the world. Orthoptera: Caelifera. China Forestry Pub. Beijing, 1266pp.

(Received for publication October 21 2009;

revised December 3 2009; accepted December 7 2009) 